\title{
Ordförrådsutveckling hos arabisk- svensktalande och turkisk-svensktalande barn i förskoleåldern och vid skolstart
}

\author{
Av UTE BOHNACKER, RIMA HADDAD, JOSEFIN \\ LINDGREN, LINNÉA ÖBERG \& BUKET ÖZTEKIN
}

\begin{abstract}
Bohnacker, Ute, ute.bohnacker@lingfil.uu.se, Professor, Department of Linguistics and Philology, Uppsala University; Haddad, Rima, rima.haddad@lingfil.uu.se, PhD student, Department of Linguistics and Philology, Uppsala University; Josefin Lindgren, josefin.lindgren@, tu-dortmund.de, Postdoctoral Researcher, Lehrstuhl Linguistik des Deutschen, Schwerpunkt Deutsch als Fremdsprache/Deutsch als Zweitsprache, Technische Universität Dortmund; Linnéa Öberg, linnea.oberg@lingfil.uu.se, PhD student, Department of Linguistics and Philology, Uppsala University; Buket Öztekin, buket.oztekin@lingfil.uu.se, Postdoctoral Research Assistant, Department of Linguistics and Philology, Uppsala University. "The lexical development of Arabic/Swedish-speaking and Turkish/Swedish-speaking children in preschool and first grade". Språk och stil NF 31:1, 2021, pp. 75-107.
\end{abstract}

This paper investigates the receptive and expressive vocabulary skills of 202 Arabic/Swedish-speaking and Turkish/Swedish-speaking bilingual children aged 4-7 growing up in Sweden, in their home/minority language (Arabic, Turkish) and in Swedish. We explore how vocabulary is affected by age, age of onset, socio-economic status (SES), and minority language exposure in the family (via parents) and via home-language (mother tongue) instruction. The comprehension and production of nouns and verbs was assessed with the Arabic, Turkish and Swedish versions of the Cross-linguistic Lexical Tasks (CLTs, Haman et al. 2015). Background information was collected via a parental questionnaire. In this cross-sectional study, there was a clear and positive effect of age on receptive and expressive vocabulary scores, though the effect was more pronounced for the majority language Swedish, and less so for the home language. Length of exposure had a positive effect on Swedish scores. For minority language vocabulary, language use in the home played an important role: Children whose parents mostly spoke Arabic or Turkish to them had significantly higher vocabulary scores in Arabic/Turkish than other children. For neither language was there any effect of SES (parental education). These results from a Swedish context complement vocabulary studies of other language combinations and reveal the importance of input for the development of receptive and expressive vocabulary in bilingual children.

Keywords: Arabic, Cross-linguistic Lexical Task (CLT), input, minority language, Swedish, SES, Turkish, vocabulary. 


\section{Inledning}

Ord utgör en central del av språket. Barns ordförråd utvecklas starkt med stigande ålder och inlärning av nya ord fortsätter livet ut. Ett välutvecklat ordförråd behövs för att man ska kunna använda ett språk i olika sammanhang och ett otillräckligt ordförråd i tidig ålder kan få negativa konsekvenser för barns möjligheter att tillgodogöra sig skolundervisning. Detta gäller både ordförståelse, d.v.s. receptiva färdigheter, och ordproduktion, d.v.s. expressiva färdigheter. Jämfört med en rad andra länder är barns ordinlärning i Sverige relativt outforskad. Överlag saknas större studier av hur ordförrådet utvecklas hos barn i äldre förskoleåldern, samt hos flerspråkiga barn i Sverige (se avsnitt 1.2).

Barns ordkunskap och ordförråd kan mätas på flera sätt, där en vanlig metod är bildbaserade muntliga ordförrådstest, särskilt för barn i förskoleålder och tidig skolålder (3-9 år). ${ }^{1}$ Ordförståelse undersöks genom att barnet får höra testordet och ska peka ut rätt bild (utav flera bilder på samma sida). Ordproduktion undersöks genom att barnet ska benämna ett antal objekt eller händelser som var och en visas på bild. De flesta ordförrådstest som används med barn i Sverige idag, t.ex. Peabody Picture Vocabulary Test, PPVT-IV (Dunn \& Dunn 2007), utvecklades ursprungligen för ett annat språk, oftast engelska, och har sedan översatts till svenska (se exempelvis Ahlström \& Ljungman 2011). Ofta mäter de antingen ordförståelse eller ordproduktion. Det saknas mer omfattande ordförrådstest som är utvecklade för svenska och anpassade till barn i förskole- och tidig skolålder. För barn som växer upp i Sverige med flera språk räcker det emellertid inte med en bedömning av deras ordkunskaper på svenska för att kunna ge en rättvis bild av ordförrådet. Ordförrådet hos flerspråkiga är fördelat över flera språk (s.k. distributed lexicon, Pearson m.fl. 1993, Kroll \& de Groot 2007), och att enbart mäta ordkunskaper i ett språk brukar grovt underskatta storleken på flerspråkigas ordförråd.

Föreliggande studie bygger på ett nytt instrument för bedömning av ordförrådet som kan användas på flera språk. Studien undersöker med hjälp av jämförbara test det receptiva och expressiva ordförrådet hos 202 flerspråkiga barn som talar arabiska och svenska respektive turkiska och svenska. Vi jämför grupperna med varandra och utforskar sambandet mellan ordförrådsutveckling och ålder, startålder, socio-ekonomisk status och olika exponeringsfaktorer.

\footnotetext{
${ }^{1}$ Ibland genomförs även andra typer av ordförrådstest, främst med något äldre barn, exempelvis uppgifter där barn ska förklara eller definiera ord, eller där de på tid ska säga så många liknande eller semantiskt relaterade ord de kan komma på.
} 
Ordförståelsen är generellt bättre än ordproduktionen, och detta gäller även för barn (Fenson m.fl. 1994, Haman m.fl. 2017a, Lindgren 2017). Den individuella variationen är ofta stor för barn i samma ålder; detta gäller för enspråkiga barn men i ännu högre utsträckning för barn som växer upp med flera språk. Ordförrådet är den del av språket som påverkas allra mest av input eller exponering, jämfört med exempelvis syntax eller fonologi (Unsworth 2013, Thordardottir 2014). Eftersom mängden och kvaliteten ${ }^{2}$ på den språkliga input som flerspråkiga barn får varierar, uppstår stora individuella skillnader i flerspråkiga barns ordförrådsutveckling. Ändå förväntas flerspråkiga barn som växer upp i Sverige utveckla sitt svenska ordförråd under (för)skoletiden och sedan uppnå skolans kunskapsmål på samma villkor som enspråkiga barn. Även beträffande det andra språket (d.v.s. hemspråket eller minoritetsspråket) kan inputen och stödet för språket variera, så att vissa barn endast utvecklar ett begränsat receptivt ordförråd medan andra har ett rikt ordförråd som de också själva använder i tal.

\subsection{Forskning utanför Sverige}

Flerspråkiga barns ordförråd utvecklas ofta tydligt på majoritetsspråket, d.v.s. på det språk som talas i samhället och i skolsammanhang, där både ordförståelsen och ordproduktionen ökar med stigande ålder (Cobo-Lewis m.fl. 2002a, Gathercole m.fl. 2013, Buac m.fl. 2014, Gagarina m.fl. 2014, Haman m.fl. 2017a). För minoritetsspråket eller hemspråket, d.v.s. det språk som inte talas i samhället i stort utan framför allt i hemmet (och/eller av en mindre samhällsgrupp), är barns ordförrådsutveckling med ålder ofta mindre tydlig. Flera studier har funnit att utvecklingen förändras i samband med barnets förskolestart eller skolstart, till följd av en förändring i input: Ordförrådet $\mathrm{i}$ minoritetsspråket växer då långsammare än tidigare, växer långsammare än $i$ majoritetsspråket, och för en del barn stagnerar det eller till och med försvagas (Boeschoten \& Verhoeven 1986, Leseman 2000, Gathercole m.fl. 2013, Hoff m.fl. 2014, Gagarina m.fl. 2017, Montanari m.fl. 2018).

Internationella studier visar att flerspråkiga barn ofta presterar lägre på ordförrådstest på majoritetsspråket än jämnåriga enspråkiga barn (Vermeer

\footnotetext{
${ }^{2}$ Med kvalitet avses hur varierad inputen är, d.v.s. olika språkliga aktiviteter och inputkällor. Kvaliteten kan mätas via lexikal diversitet i sampel av barnriktat tal (inkl. lågfrekventa ord), dekontextualiserat språk (sagor, förklarande text osv.), läsaktiviteter med barnet, eller antalet olika samtalspartners och inputkällor (Hart \& Risley 1995, Unsworth 2013).
} 
2001, Bialystok m.fl. 2010, Rhys \& Thomas 2013, Altman m.fl. 2017, Haman m.fl. 2017a, Meir \& Armon-Lotem 2017). Flerspråkiga barns lägre prestationer (d.v.s. lägre än jämnåriga enspråkiga barngrupper eller lägre än testnormen för enspråkiga om en sådan norm finns) bör dock tolkas med försiktighet. För det första tar sådana jämförelser endast hänsyn till barnens ordkunskaper i ett språk och bortser från ordkunskaper i det andra, trots att vi vet att ordförrådet är fördelat över båda språken. För det andra brukar en ansenlig andel flerspråkiga barn prestera i paritet med jämnåriga enspråkiga barn på ordförrådstest (Bialystok m.fl. 2010, Thordardottir 2011, Gathercole m.fl. 2013). Som bekant kan skillnader i medelvärden för olika grupper dölja stora och viktiga skillnader mellan individer, och att ignorera denna individuella variation kan leda till felaktiga påståenden och populärvetenskapliga tolkningar som att »alla flerspråkiga har sämre ordkunskaper än enspråkiga». För det tredje har mängden input visat sig ha en stark inverkan: mer input på ett språk leder till bättre resultat på ordförrådstest på det språket (Gathercole m.fl. 2013, Thordardottir 2011, Prevoo m.fl. 2014). Detsamma kan tänkas vara fallet för input med högre kvalitet, vilket dock sällan undersökts. Mer input (eller exponering) leder inte bara till bättre ordförståelse och ett större ordförråd, utan även till att barnet använder språket i större utsträckning med samtalspartners, vilket i sin tur leder till mer input. Pearson (2007 s. 400-401) beskriver effekten av input som en självförstärkande cirkulär process (self-reinforcing input-proficiency-use cycle):

Of all the relevant factors that parents or communities have some control over, quantity of input is the largest. Without it, no learning takes place. Without enough of it, learning can take place, but children do not reach a comfort level in the language so that they will willingly use it [...]. If children use a minority language they invite more input so the cycle is self-reinforcing [...]. A greater amount of input leads to greater proficiency, which leads to more use, which invites more input and the cycle starts again. If children do not use the heritage language, then they are using a different language and thereby getting less input in the heritage language; they develop less proficiency, which leads to using it even less, and that in turn, leads to getting even less input in that language. (Pearson 2007 s. 400)

Ordförrådsutvecklingen verkar även vara relaterad till familjens bakgrund; som grupp presterar flerspråkiga barn från familjer med hög socio-ekonomisk status (SES) ofta bättre på ordförrådstest än flerspråkiga barn från familjer med låg SES (Leseman 2000, Cobo-Lewis m.fl. 2002a, Buac m.fl. 2014, Calvo \& Bialystok 2014). Dessutom presterar flerspråkiga barn med hög SES-bakgrund ofta på samma nivå som enspråkiga barn på ordförrådstest i majoritets- 
språket (Calvo \& Bialystok 2014). Som förklaring anförs ofta att barn från familjer med hög SES får bättre tillgång till språkliga aktiviteter som stimulerar utveckling och ordinlärning (Hart \& Risley 1995, Pearson 2007). När effekter av SES på flerspråkiga barns ordförråd kan påvisas brukar det handla om majoritetsspråket. Effekten av SES på minoritetsspråket är otydlig eller t.o.m. den motsatta. Exempelvis presterade förskolebarn från familjer med låg SES i vissa studier bättre på ordförrådsuppgifter i minoritetsspråket än de med hög SES (Cobo-Lewis m.fl. 2002b), medan andra studier inte kunnat hitta ett sådant samband (Leseman 2000, Buac m.fl. 2014, Prevoo m.fl. 2014). SES kan dock mätas på olika sätt (exv. föräldrars utbildning, yrken, familjens inkomst, bostadsområde), och det skiljer sig mellan länder huruvida SES påverkar barns utveckling exempelvis via tillgång till vård och skola. I Sverige har flerspråkiga barns ordinlärning i relation till familjens SES knappt undersökts (se nedan).

Faktorer som ålder, språklig exponering (input) och SES kan inte bara slå olika för majoritets- och minoritetsspråket, utan även ha olika starkt inflytande beroende på vilka aspekter av ordförrådet som undersöks - ordförståelse eller ordproduktion. Dessutom verkar språkkombinationen spela roll, närmare bestämt språksläktskap och förekomst av kognater, eftersom barn som växer upp med språk med många kognater behöver färre exponeringstillfällen för att lära sig ord som låter (nästan) likadana och betyder samma sak (Sheng m.fl. 2016). En riklig förekomst av kognater skulle alltså kunna snabba på ordinlärningen och därmed i viss mån väga upp den negativa effekten av begränsad exponering för ordinlärningen (Lindgren \& Bohnacker 2020).

\subsection{Forskning i Sverige}

I Sverige finns endast få publicerade studier om ordförrådsutvecklingen hos flerspråkiga barn. Holm och Rejnö-Habte Selassie (2017) fann att 2-3-åriga flerspråkiga barn (med olika hemspråk) från ett socio-ekonomiskt utsatt område presterade lägre på ett svenskt förståelsetest än flerspråkiga barn från mer privilegierade områden (förståelsetestet avsåg dock inte bara ord, och hemspråken undersöktes ej). I Holm och Rejnö-Habte Selassies undersökning sågs ingen åldersutveckling, men barngruppen hade ett snävt åldersspann och stor individuell variation.

I en mer omfattande studie fann Ganuza och Hedman (2019), i enlighet med internationell forskning, att 6-12-åriga somalisk-svensktalande skolelevers ordförråd utvecklades starkare på majoritetsspråket (svenska) än på hemsprå- 
ket (somaliska). De kunde även visa en effekt av input, där elever som deltog i modersmålsundervisning på somaliska presterade bättre än elever som inte gjorde det. Modersmålsundervisningens roll i ordförrådsutvecklingen har annars knappt undersökts, inte heller internationellt.

Lindgren och Bohnacker (2020) fann att 4-6-åriga tysk-svensktalande barns ordförråd utvecklades starkare på svenska än på tyska, men även att barnen presterade bättre på de ord som var kognater i de båda språken. För samma tysk-svenska barn samt för en grupp åldersmatchade turkisk-svensktalande barn kunde Bohnacker m.fl. (2016) visa att mer input på minoritetsspråket (tyska, turkiska) ledde till bättre ordproduktion hos 4-6-åriga barn (majoritetsspråket svenska undersöktes ej). Barn vars föräldrar huvudsakligen talade tyska eller turkiska med varandra och med barnet hade ett större expressivt ordförråd på detta språk. För de barn som blev mindre exponerade för minoritetsspråket från föräldrarna sågs en kompenserade »kompiseffekt»: Barn med tysktalande respektive turkisktalande vänner hade ett större expressivt ordförråd på det språket än de utan sådana vänner. Öztekin (2019) fann i en tvärsnittsstudie av 4-7-åriga turkisk-svensktalande barn att den receptiva och expressiva ordkunskapen hos de yngsta barnen var bättre på turkiska än på svenska, men att ordförrådet sedan utvecklades mer på svenska än på turkiska. Samma trend med tydligare ordförrådsutveckling på majoritetsspråket än på minoritetsspråket bekräftades när 10 barn följdes individuellt över två års tid: Medan samtliga barn förbättrade sitt svenska ordförråd, var så inte fallet för turkiska; vissa barn stagnerade eller presterade till och med något lägre vid 6 års ålder än vid 4 år (Öztekin 2019 kap. 6). SES verkade inte ha någon effekt på barnens ordkunskap. Deltagarna från Öztekins tvärsnittsstudie ingår även i föreliggande studie.

\section{Denna studie}

Vi presenterar här resultat för ordförrådsutvecklingen hos 202 flerspråkiga barn från 4 till 7 år i den hittills största tvärsnittsstudien i Sverige, som dessutom undersöker barnens båda språk (arabiska och svenska respektive turkiska och svenska). I studien används jämförbara test på alla tre språken och testen undersöker både ordförståelse och ordproduktion. Arabiska och turkiska har endast få ord som är kognater med svenska, och de ordförrådstest som används innehåller inga svensk/arabiska kognater och nästintill inga svensk/turkiska 
kognater (4 av 120 testord). Barnen kan därmed inte få lexikal hjälp från sitt minoritetsspråk vid inlärningen av ord i majoritetsspråket svenska, eller vice versa. Språkkombinationerna har valts eftersom det finns stora grupper arabisktalande och turkisktalande vuxna och barn i Sverige och vi vet nästan ingenting om dessa barns språkinlärning och flerspråkiga utveckling. ${ }^{3}$

Fokus i undersökningen ligger på ordförrådsutvecklingen med stigande ålder, likheter och skillnader mellan grupperna, samt bakomliggande faktorer för barns varierande resultat. Följande forskningsfrågor ställs:

- Sker en ordförrådsutveckling med stigande ålder för både majoritetsspråket svenska och för hemspråket/minoritetsspråket arabiska respektive turkiska?

- Sker en utveckling med stigande ålder för både ordförståelse och ordproduktion?

- Skiljer sig de två flerspråkiga grupperna åt?

- Kan variationen mellan barn förklaras med hjälp av bakgrundsfaktorer, så som skillnader i språklig exponering eller socio-ekonomisk status?

I ett svenskt sammanhang har dessa frågor inte undersökts. Frågorna är dock välmotiverade utifrån tidigare forskning $\mathrm{i}$ andra länder och kontexter (se avsnitt 1). Vi kan därmed diskutera våra resultat för arabiska/svenska och turkiska/ svenska i relation till internationella studier. Kommer mönstren i våra data från Sverige vara desamma? Om ja, vad kan detta säga oss? Och tvärtom, om det visar sig att ordförrådsutvecklingen eller påverkan av bakgrundsfaktorer skiljer sig markant från det som rapporterats i litteraturen, vad skulle anledningen kunna vara? Är exempelvis den svenska kontexten annorlunda?

\section{Metod}

Detta avsnitt beskriver deltagarna, testmaterialet, genomförandet och val av statistisk analys.

\footnotetext{
${ }^{3}$ Andra språkkombinationer skulle givetvis vara lika intressanta att undersöka, men just för arabiska, turkiska och svenska har vi lingvistisk expertis och jämförbara, reliabla bedömningsmaterial.
} 


\subsection{Deltagare}

I studien ingick 202 flerspråkiga förskolebarn och barn i första klass (4-7 år) från ett större forskningsprojekt, det s.k. BiLI-TAS-projektet (Bohnacker 2013-2019) om arabisktalande och turkisktalande barn med och utan språkstörning i Sverige. Inget barn i föreliggande studie hade någon känd språkstörning, neuropsykiatrisk diagnos eller obehandlad syn- eller hörselnedsättning. Alla barn hade antingen arabiska eller turkiska som hemspråk i familjen. Barnen var i åldern 4;0-8;1 (år;månad). Deltagarna var jämnt fördelade över fyra åldersgrupper, se tabell 1 .

Tabell 1. Antal deltagare.

\begin{tabular}{llllll}
\hline & 4 år & 5 år & 6 år & 7 år & Totalt \\
\hline Arabiska/svenska & 22 & 25 & 29 & 24 & 100 \\
flickor/pojkar & $12 / 10$ & $10 / 15$ & $12 / 17$ & $16 / 8$ & $50 / 50$ \\
\hline Turkiska/svenska & 25 & 23 & 26 & 28 & 102 \\
flickor/pojkar & $13 / 15$ & $13 / 10$ & $15 / 11$ & $14 / 14$ & $55 / 47$ \\
\hline Totalt & 47 & 48 & 55 & 52 & 202 \\
\hline
\end{tabular}

Not. Tre turkisktalande barn i 7-årsgruppen hade nyligen fyllt 8 år vid testtillfället.

Barnen rekryterades från drygt 100 förskolor och skolor i fyra större städer $\mathrm{i}$ östra Mellansverige, merparten i Storstockholmsområdet. Barnens föräldrar gav skriftligt samtycke till deltagandet. Föräldrarna fyllde även i en enkät med frågor om barnets språkutveckling, familjens bakgrund och språkanvändning. Alla fyra- och femåringar samt ett fåtal sexåringar gick i förskola. Alla andra sexåringar gick i förskoleklass. Sjuåringarna gick antingen i förskoleklass eller i första klass. Barnen fick regelbunden input på båda språken men mängden på respektive språk varierade (se nedan). Alla barn talade dock båda språken tillräckligt väl för att, utöver ordförrådstesten, kunna berätta till bilder och besvara frågor på båda språken.

Nästan alla barn har regelbundet exponerats för arabiska respektive turkiska från födseln $(96 \%, 193 / 202)$. För fem barn började exponeringen något senare (eftersom de vid födseln först exponerades för ett annat språk, så som kurdiska), och för ytterligare fyra saknades denna information i enkätsvaren. För de allra flesta barnen $(85 \%, 171 / 202)$ hade båda föräldrarna arabiska respektive turkiska som modersmål och 73 \% talade huvudsakligen arabiska res- 
pektive turkiska med barnet (147/202). De flesta barnen $(67 \%, 134 / 202)$ talade också huvudsakligen arabiska respektive turkiska med båda föräldrarna.

Vad beträffar majoritetsspråket svenska så började exponeringen (s.k. age of onset, AoO, startålder) för de allra flesta barnen $(83 \%, 167 / 202)$ inte under det första levnadsåret, utan ett, två eller tre år senare. Exponering för svenska skedde framför allt via (för)skolan, i vilken samtliga barn gick vid testtillfället. De flesta barnen hade minst 2 års exponering för svenska, oftast betydligt mer. Några få hade kortare exponeringslängd. Vi valde att inte a priori exkludera barn med sen $\mathrm{AoO}$ eller kortare exponeringslängd, snarare ville vi undersöka testresultaten i relation till exponeringslängd (se avsnitt 3.2.3). Så länge barnen kunde genomföra ordförrådstesten på båda språken inkluderades de i studien. Exponeringslängden för svenska var i genomsnitt något längre i den turkisktalande gruppen än i den arabisktalande gruppen, vilket sannolikt har att göra med olika migrationsmönster: $92 \%$ av de turkisktalande barnen var födda i Sverige (94/102) jämfört med $54 \%$ av de arabisktalande barnen (54/100). Medan $79 \%$ av de turkisktalande barnen (81/102) började exponeras för svenska före 3 års ålder, skedde detta endast för $46 \%$ av de arabisktalande barnen (46/100).

De allra flesta barnen växte upp med två språk (arabiska och svenska, turkiska och svenska) men $12 \%(25 / 202)$ exponerades dessutom regelbundet för ett tredje språk i hemmet via föräldrarna, vanligtvis kurdiska. Endast $4 \%$ $(8 / 202)$ av barnen talade det tredje språket aktivt.

Merparten av barnen växte upp i multikulturella, mångspråkiga storstadsområden med förhållandevis låg socio-ekonomisk status. Det vore dock förhastat att utifrån bostadsområdena dra slutsatser om de individuella familjernas SES. Enkätsvaren visade att föräldrarnas yrke och utbildningsnivå varierade stort, från 0 till 8 på den 9-gradiga ISCED 2011 skalan (International Standard Classification of Education, UNESCO Institute for Statistics 2012), där 0 motsvarar mindre än 3 års skola och 8 motsvarar doktorsexamen. Många föräldrar angav att de hade gått ut gymnasiet (ISCED 3). Föräldrars genomsnittliga utbildning för arabiska/svenska var ISCED 4,2 (SD: 1,8); för turkiska/ svenska var genomsnittet ISCED 3,4 (SD: 1,6). I den arabisktalande gruppen fanns alltså en något större andel högskoleutbildade föräldrar än i den turkisktalande gruppen. 


\subsection{Material, genomförande och analys}

\subsubsection{CLT}

För att undersöka barnens ordförråd användes de svenska, arabiska och turkiska versionerna av Cross-linguistic Lexical Tasks (CLT, Haman m.fl. 2015). CLT är bildbaserade ordförrådstest, ett språkbedömningsmaterial som skapades inom ett europeiskt forskningsnätverk (COST Action IS0804) år 20092013. CLT är särskilt framtaget för den sena förskoleåldern (3-6 år) och finns i nuläget för 29 språk (nya språkversioner tillkommer kontinuerligt, se http:// psychologia.pl/clts/\#projects). Svårighetsgraden är anpassad till att enspråkiga femåringar med typisk språkutveckling ska få ett relativt högt resultat. Äldre barn förväntas alltså klara de flesta uppgifterna; syftet är att mäta barns förmåga att klara av uppgifter på en viss nivå (jfr Frylmark 2006). I en storskalig studie sågs liknande resultat på CLT för 17 språk (Haman m.fl. 2017a), vilket har validerat testets lämplighet. Ordförrådet som testas med CLT är grundläggande, vardagsnära och relativt barncentrerat; orden är konkreta (ej abstrakta) så att de lätt kan avbildas.

CLT består av fyra delar, substantivförståelse, verbförståelse, substantivproduktion samt verbproduktion. Detta är relativt ovanligt, då de flesta ordförrådstesten antingen testar enbart ordförståelse eller ordproduktion och inte båda, och ofta endast substantiv, trots att både substantiv och verb är viktiga delar av basordförrådet. Sammanlagt innehåller CLT 120 testord och 8 övningsord, jämnt fördelade över förståelse och produktion. Förståelseuppgifterna går ut på att testledaren ställer en fråga (t.ex. Var är tandborsten? för substantivförståelse och Vem kryper? för verbförståelse) och barnet svarar genom att peka på rätt bild av fyra möjliga. Expressiva ordkunskaper testas genom bildbenämningsuppgifter där barnet får se en bild och ska säga det ord som passar bäst till bilden, d.v.s. svara på frågorna Vad är det? för substantivproduktion och Vad gör han/hon? eller Vad händer här? för verbproduktion. Varje uppgift presenteras på en separat sida och alla bilder är i färg. Uppgifterna är typiska för tester av barns ordförråd.

Det som gör CLT annorlunda än andra ordförrådstest är att de olika språkversionerna inte är översättningar utan anpassade till respektive språk. Varje språkversion är unik, men alla är baserade på en gemensam lista med grundläggande begrepp för objekt och handlingar/händelser (motsvarande substantiv och verb) och en gemensam bilddatabas.

Målorden i varje språkversion är utvalda utifrån såväl den språkliga som kulturella kontexten; orden ska vara kulturellt lämpliga och ha olika svårig- 
hetsgrad på det aktuella språket. Varje ords svårighetsgrad bestämdes via dess morfofonologiska komplexitet och age of acquisition (åldern då barn lär sig ordet) framtagen i en storskalig studie (se Haman m.fl. 2015 för en mer utförlig beskrivning av hur CLT konstruerades). Innan CLT skapades saknades jämförbara ordförrådstest för olika språk för den aktuella åldersgruppen. Vi har själva medverkat i framtagningen och vidareutvecklingen av de svenska och turkiska versionerna (Ringblom m.fl. 2014, Ünal-Logacev m.fl. 2013), samt av arabiska CLT för de arabiska varieteter som talas mest av barnfamiljer i Sverige, d.v.s. irakiska, libanesiska, palestinska och syriska (Haddad 2017).

Barnen gjorde ordförrådstesten som en del av en omfattande datainsamling, där även olika berättandeuppgifter och repetition av nonsensord ingick. Datainsamlingen på svenska och på arabiska respektive turkiska genomfördes vid olika tillfällen (med minst tre dagars mellanrum) av testledare som var modersmålstalare av respektive språk (d.v.s. författarna och assistenter). Eftersom talade arabiska varieteter skiljer sig mycket åt, eftersträvades att testledarens dialekt matchade barnets och att lämpliga dialektalternativ till testorden användes. ${ }^{4}$ Datainsamlingen skedde i ett avskilt rum på (för)skolan, i hemmet eller på ett center där aktiviteter för arabisk/turkisktalande barn anordnades. Testtillfällena spelades in med ljud och bild. Genomförandet av CLT tog 10-20 minuter. Standardproceduren beskriven i Haman m.fl. (2015) följdes. Testledaren antecknade barnens respons i testblanketten. Svaren verifierades efteråt mot inspelningen.

\subsubsection{Bakgrundsenkät}

Föräldrarna till barnen fyllde i en enkät på valfritt språk (svenska, arabiska eller turkiska); om så önskades, administrerades enkäten i stället muntligt via telefon. Enkäten innehöll 36 frågor om barnets språkutveckling, exponering, familjens bakgrund och språkanvändning. I föreliggande studie analyseras svaren på ett begränsat urval av frågor och relateras till resultaten på ordförrådstesten (se nästa avsnitt).

\footnotetext{
${ }^{4}$ Enligt uppgift talade de flesta arabisktalande barnen (78 \%) dialekter från Levanten (syriska, palestinska, libanesiska) och resten irakiska eller egyptiska. Många barn exponerades dock för flera dialekter, och delvis även för modern standardarabiska. Se Bohnacker m.fl. (under granskning) om framtagningen av de arabiska CLT-dialektversionerna.
} 


\subsubsection{Poängsättning och analys}

Maxpoängen var 60 poäng för såväl ordförståelse som ordproduktion. Alla barn genomförde alla deltest. Det totala antalet svar var 48480 (=202 barn x 2 språk x 120 testord, d.v.s. 60 för förståelse +60 för produktion). Författarna poängsatte barnens svar på alla uppgifterna. Ett (1) poäng gavs per rätt svar. För ordförståelsedelarna gavs rätt svar för pekning på rätt bild. För ordproduktion innebar rätt svar att säga målordet, d.v.s. det substantiv eller verb som bilden visade, eller en dialektal motsvarighet, exv. dabdab, zahaf eller haba »krypa» på arabiska CLT, emekliyor »kryper» på turkiska CLT, eller krypa på svenska CLT, i respons till en bild med en bebis som kryper på golvet. Synonymer till målordet (t.ex. stövel och känga) och mer specifika ord som överensstämde med bildens innehåll godkändes också som rätt svar, t.ex. mura för målordet bygga (bilden föreställer en man som bygger en mur/husvägg). Olika böjningsformer (exv. krypa/kryper) godkändes. Avvikande uttal godkändes så länge målordets lemma fortfarande var igenkännbart. Poängsättningen av samtliga svar kontrollerades noggrant, så att den var konsekvent och följde samma principer för alla tre språk. Oklara fall diskuterades i forskargruppen tills konsensus uppnåddes. ${ }^{5}$ Detta resulterade i fyra olika ordförrådsmått för varje barn.

CLT-resultaten undersöktes först deskriptivt för alla barn i varje grupp. Sedan analyserades resultaten i relation till ålder och språkgrupp genom fyra linjära regressionsanalyser, en för förståelse och en för produktion på majoritetsspråket svenska, samt en för förståelse och en för produktion på minoritetsspråket. De oberoende variablerna (prediktorer) var barnets ålder (i månader), språkgrupp och interaktionen mellan ålder och grupp; den beroende variabeln var antalet poäng.

Därefter analyserades effekten av ett antal bakgrundsfaktorer: 1) exponeringslängd för svenska, 2) exponering för minoritetsspråket via föräldrarna, 3) modersmålsundervisning, 4) SES. Effekten av exponeringslängd för svenska undersöktes med linjära regressionsanalyser, en för förståelse och en för produktion på de två språken. Resterande faktorer operationaliserades som nedan beskrivet; barnen kategoriserades därefter i två grupper, och gruppernas medelvärden på CLT-resultaten jämfördes med Welchs t-test.

Med Age of onset (AoO) avses tidpunkten då barnet börjar få regelbunden svensk input; $i$ vårt sampel motsvarar detta ofta, men inte alltid, tidpunkten

\footnotetext{
${ }^{5}$ Rättningsprinciperna inkl. exempel sammanfattades i en omfattande rättnings-/kodningsbok (Bohnacker 2018), som följdes av alla som kodade datan.
} 
när barnet börjar gå i svensk förskola. AoO räknades om till exponeringslängd genom subtraktion av $\mathrm{AoO}$ (i månader) från barnets kronologiska ålder (i månader). Exponeringslängd för arabiska respektive turkiska kunde inte undersökas statistiskt eftersom den knappt varierade ( $97 \%$ exponerades från födseln).

Angående exponering för minoritetsspråket har vi i föreliggande studie valt att koncentrera oss på föräldrars språk till barnet (parent to child), vilket internationellt anses vara den viktigaste exponeringsfaktorn när det gäller förskolebarn. ${ }^{6}$ I enkäten angav föräldrarna hur mycket var och en talade vilket språk med barnet. Detta gjordes på separata skalor för varje förälder, där den sjugradiga skalan gick från »(nästan) bara arabiska/turkiska» till »(nästan) bara svenska» (andra fördelningar, exv. ett tredje språk, kunde också anges). Barnen delades in i två grupper: »mestadels arabiska/turkiska» om båda föräldrar angav att de nästan bara eller mestadels talade arabiska/turkiska med barnet, och »annat». »Annat» betydde att minst en förälder i betydande utsträckning talade med barnet på ett annat språk än arabiska/turkiska (exv. svenska). ${ }^{7}$

Modersmålsundervisning ger barn ytterligare exponering för minoritetsspråket, även om det ofta handlar endast om 40-60 min/vecka, och signalerar att detta språk är viktigt. Utifrån enkätsvaren delades barnen in i två grupper, de som deltog i modersmålsundervisning i antingen kommunal eller privat regi, och de som inte deltog.

Familjens SES operationaliserades via föräldrarnas utbildningsnivå. Varje förälders utbildning kodades enligt den 9-gradiga ISCED 2011 skalan. För varje barn beräknades ett medelvärde baserad på båda föräldrars utbildningsnivå, eller för ensamstående föräldrar dennes utbildningsnivå. Barnen delades in i två grupper: »låg SES» (motsvarande ISCED-nivåerna 0-3, d.v.s. mindre än 3 års skola upp till gymnasium) och »hög SES» (ISCED-nivåerna 4-8, d.v.s. viss eftergymnasial utbildning upp till doktorsexamen).

\footnotetext{
${ }^{6}$ Enkätdatan innehåller inte bara information om språklig input från föräldrarna utan även från andra personer, så som syskon, släktingar och vänner/lekkamrater, samt media och olika språkliga aktiviteter. Effekterna av sådan exponering tas upp i författarnas doktorsavhandlingar och framtida studier.

${ }^{7}$ För enkelhetens skull begränsar vi oss till denna tudelning i föreliggande studie.
} 


\section{Resultat}

Tabell 2 och 3 visar resultaten för de båda grupperna för de fyra CLT-deltesten på respektive språk.

Tabell 2. Antal poäng CLT, arabisktalande gruppen ( $\mathrm{N}=100)$. Maxpoäng per deltest $=60$.

\begin{tabular}{lllll}
\hline & $\begin{array}{l}\text { Arabiska } \\
\text { förståelse }\end{array}$ & $\begin{array}{l}\text { Arabiska } \\
\text { produktion }\end{array}$ & $\begin{array}{l}\text { Svenska } \\
\text { förståelse }\end{array}$ & $\begin{array}{l}\text { Svenska } \\
\text { produktion }\end{array}$ \\
\hline Medel (SD) & $47,5(7,5)$ & $32,7(12,3)$ & $45,6(10,8)$ & $30,8(11,7)$ \\
Min-Max & $25-59$ & $1-53$ & $18-60$ & $10-53$ \\
\hline
\end{tabular}

Tabell 3. Antal poäng CLT, turkisktalande gruppen ( $\mathrm{N}=102)$. Maxpoäng per deltest $=60$.

\begin{tabular}{lllll}
\hline & $\begin{array}{l}\text { Turkiska } \\
\text { förståelse }\end{array}$ & $\begin{array}{l}\text { Turkiska } \\
\text { produktion }\end{array}$ & $\begin{array}{l}\text { Svenska } \\
\text { förståelse }\end{array}$ & $\begin{array}{l}\text { Svenska } \\
\text { produktion }\end{array}$ \\
\hline Medel (SD) & $54,2(6,6)$ & $39,1(11,7)$ & $50,2(9,0)$ & $34,9(11,1)$ \\
Min-Max & $26-60$ & $3-60$ & $18-60$ & $8-54$ \\
\hline
\end{tabular}

Föga förvånande är resultaten för ordförståelsen signifikant högre än för ordproduktion i båda grupperna. Detta gäller både för hemspråket/minoritetsspråket (arabiska, turkiska) och för svenska. ${ }^{8}$ Spridningen är mycket stor på samtliga deltest $\mathrm{i}$ båda grupperna, både gällande standardavvikelsen och skillnaden mellan lägsta och högsta poäng. Det kan till viss del förklaras med det stora åldersspannet (4;0-8;1 år). Ålderseffekter undersöks i nästa avsnitt.

\section{1 Ålder}

För att undersöka ålderseffekter samt skillnader mellan de två språkgrupperna genomfördes fyra linjära regressionsanalyser, en för varje uppgiftstyp (mino-

\footnotetext{
${ }^{8}$ I den arabisktalande gruppen är ordförståelsen signifikant högre än ordproduktionen för både arabiska $(\mathrm{t}(99)=18,4, \mathrm{p}<0,001)$ och svenska $(\mathrm{t}(99)=30,6, \mathrm{p}<0,001)$. Även i den turkisktalande gruppen är ordförståelsen signifikant högre än produktionen för både turkiska $(\mathrm{t}(101)=20,3, \mathrm{p}$ $<0,001)$ och svenska $(\mathrm{t}(101)=29,8, \mathrm{p}<0,001)$.
} 
ritetsspråk ordförståelse, minoritetsspråk ordproduktion, svensk ordförståelse, svensk ordproduktion), se tabell 4.

Tabell 4. Regressionsanalyser för ordförståelse och ordproduktion.

\begin{tabular}{|c|c|c|c|c|c|c|c|c|}
\hline & \multicolumn{2}{|c|}{$\begin{array}{l}\text { Minoritetsspråk } \\
\text { ordförståelse }\end{array}$} & \multicolumn{2}{|c|}{$\begin{array}{l}\text { Minoritetsspråk } \\
\text { ordproduktion }\end{array}$} & \multicolumn{2}{|c|}{$\begin{array}{l}\text { Svensk } \\
\text { ordförståelse }\end{array}$} & \multicolumn{2}{|c|}{$\begin{array}{l}\text { Svensk } \\
\text { ordproduktion }\end{array}$} \\
\hline & $\beta$ & $S E$ & $\beta$ & $S E$ & $\beta$ & $S E$ & $\beta$ & $S E$ \\
\hline Intercept & $28,03 * * *$ & 3,45 & 11,63 & 6,21 & $18,82 * * *$ & 4,43 & 2,64 & 5,20 \\
\hline Ålder & $0,27 * * *$ & 0,05 & $0,29 * * *$ & 0,08 & $0,40 * * *$ & 0,06 & $0,39 * * *$ & 0,07 \\
\hline $\begin{array}{l}\text { Grupp } \\
\text { BiTur/ } \\
\text { BiAra }\end{array}$ & $16,63 * * *$ & 4,81 & 15,95 & 8,66 & 5,34 & 6,18 & $-1,63$ & 7,25 \\
\hline $\begin{array}{l}\text { Ålder x } \\
\text { Grupp }\end{array}$ & $-0,14^{*}$ & 0,06 & $-0,13$ & 0,12 & $-0,01$ & 0,08 & 0,09 & 0,10 \\
\hline $\begin{array}{l}\mathrm{R}^{2} \text { (kor- } \\
\text { rigerad) }\end{array}$ & 0,32 & & 0,12 & & 0,33 & & 0,29 & \\
\hline
\end{tabular}

Not. $* \mathrm{p}<0,05, * * \mathrm{p}<0,01, * * * \mathrm{p}<0,001$. Ålder $=$ barnets ålder i månader. BiTur $=$ turkiska/ svenska, BiAra = arabiska/svenska. Utgångsgrupp i ovanstående modell är BiTur. Turkisk/ arabisk ordförståelse: $\mathrm{F}(3,198)=32,22, \mathrm{p}<0,001$. Turkisk/arabisk ordproduktion: $\mathrm{F}(3,198)=$ $10,37, \mathrm{p}<0,001$. Svensk ordförståelse: $\mathrm{F}(3,198)=34,57, \mathrm{p}<0,001$. Svensk ordproduktion: $\mathrm{F}(3$, 198) $=28,77, \mathrm{p}<0,001$.

Analyserna visar att det för samtliga uppgifter finns en signifikant ålderseffekt, d.v.s. äldre barn presterar bättre än yngre. Ålderseffekten visualiseras med punktdiagram i figur 1-2 nedan.

De arabisktalande barnen har generellt lägre antal poäng än de turkisktalande barnen; dock är denna skillnad endast signifikant för förståelsen på minoritetsspråket. Här ses en starkare ålderseffekt för de arabisktalande barnen, vilket avspeglas i regressionslinjens brantare lutning (figur 1A). ${ }^{9}$

Överlag är ålderseffekten starkare för svenska än för minoritetsspråket, vilket ses i den brantare lutningen av regressionslinjerna för svenska; detta gäller både svensk ordförståelse och ordproduktion (jfr figur 2 A-B med figur 1 A-B). Spridningen i antal poäng är mycket större för ordproduktion än ordförståelse. Ett ganska stort antal barn presterar nära maximum på ordförståelse, men så är inte fallet för ordproduktion.

${ }^{9}$ Denna starkare effekt beror troligtvis på en takeffekt på detta deltest hos den turkisktalande gruppen. 
Trots tendensen till bättre prestation med stigande ålder finns stor variation i resultaten. I de följande avsnitten undersöks huruvida bakgrunds- och miljöfaktorer kan förklara en del av denna variation.
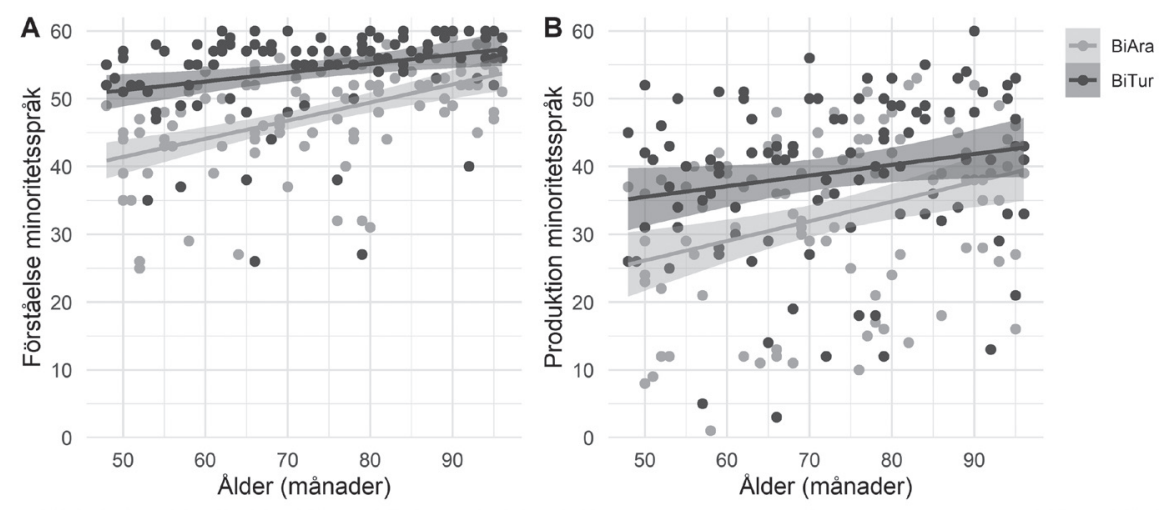

Figur 1. Ordförståelse, minoritetsspråket $(\max =60)(\mathrm{A})$ samt ordproduktion, minoritetsspråket $(\max =60)(B)$. Individuella barns resultat i relation till ålder. En punkt kan ange resultatet för fler än ett barn. Det skuggade området kring regressionslinjen ger ett konfidensintervall på \pm 1 standardfel. BiAra $=$ arabiska/svenska, BiTur $=$ turkiska/ svenska.
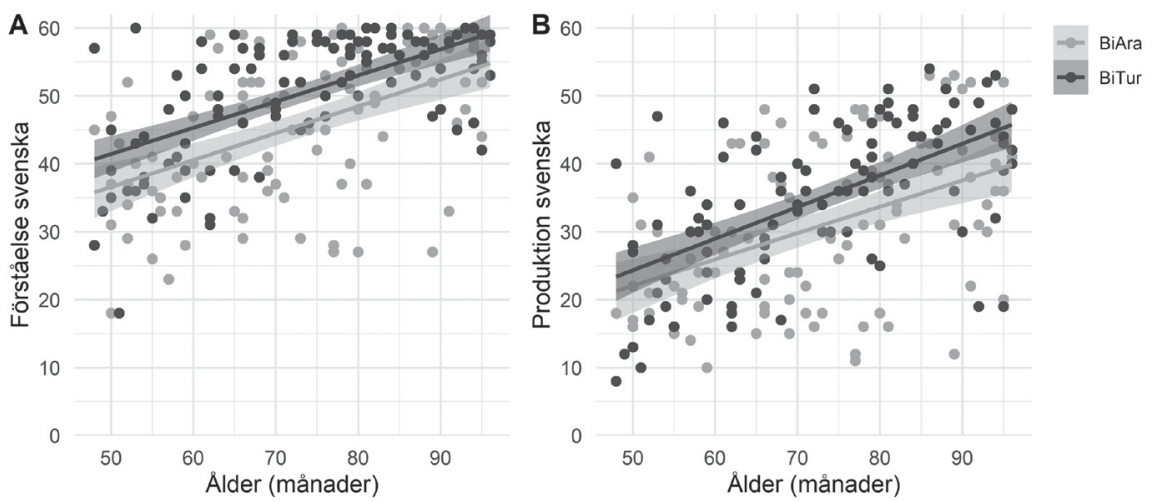

Figur 2. Ordförståelse, svenska $(\max =60)(A)$ samt ordproduktion, svenska $(\max =$ 60) (B). Individuella barns resultat i relation till ålder. En punkt kan ange resultatet för fler än ett barn. Det skuggade området kring regressionslinjen ger ett konfidensintervall på \pm 1 standardfel. BiAra $=$ arabiska/svenska, BiTur $=$ turkiska/svenska. 


\subsection{Exponeringslängd för svenska}

För att undersöka effekten av exponeringslängd på barnens svenska ordförråd genomförde vi två linjära regressionsanalyser, en för förståelse och en för produktion, se tabell 5 .

Tabell 5. Regressionsanalyser för ordförståelse och ordproduktion.

\begin{tabular}{lllll}
\hline & \multicolumn{2}{l}{ Svensk ordförståelse } & \multicolumn{2}{l}{ Svensk ordproduktion } \\
& $\beta$ & $S E$ & $\beta$ & $S E$ \\
\hline Intercept & $31,75^{* * *}$ & 1,78 & $16,05^{* * *}$ & 2,07 \\
Exponeringslängd för & $0,34^{* * *}$ & 0,04 & $0,36^{* * *}$ & 0,05 \\
svenska & & & & \\
Grupp BiTur/BiAra & 2,30 & 2,82 & -0.95 & 3,27 \\
Exponeringslängd $\mathrm{x}$ & $-0,05$ & 0,05 & $<0,01$ & 0,06 \\
Grupp & & & & \\
$\mathrm{R}^{2}($ korrigerad $)$ & 0,43 & & 0,41 & \\
\hline
\end{tabular}

Not. $* \mathrm{p}<0,05, * * \mathrm{p}<0,01, * * * \mathrm{p}<0,001$. BiTur $=$ turkiska/svenska. BiAra $=$ arabiska/ svenska. Utgångsgrupp i ovanstående modell är BiTur. Svensk ordförståelse: F(3, 196) $=51,47, \mathrm{p}<0,001$. Svensk ordproduktion: $\mathrm{F}(3,196)=47,41, \mathrm{p}<0,001$.

Analyserna visar att det finns en signifikant effekt av exponeringslängd för både svensk ordförståelse och ordproduktion, men ingen signifikant skillnad mellan de båda språkgrupperna. Exponeringseffekten visualiseras med punktdiagram i figur $3 \mathrm{~A}-\mathrm{B}$. Eftersom barnens startålder för svenska varierar mycket, är denna effekt av exponeringslängd förväntad. 

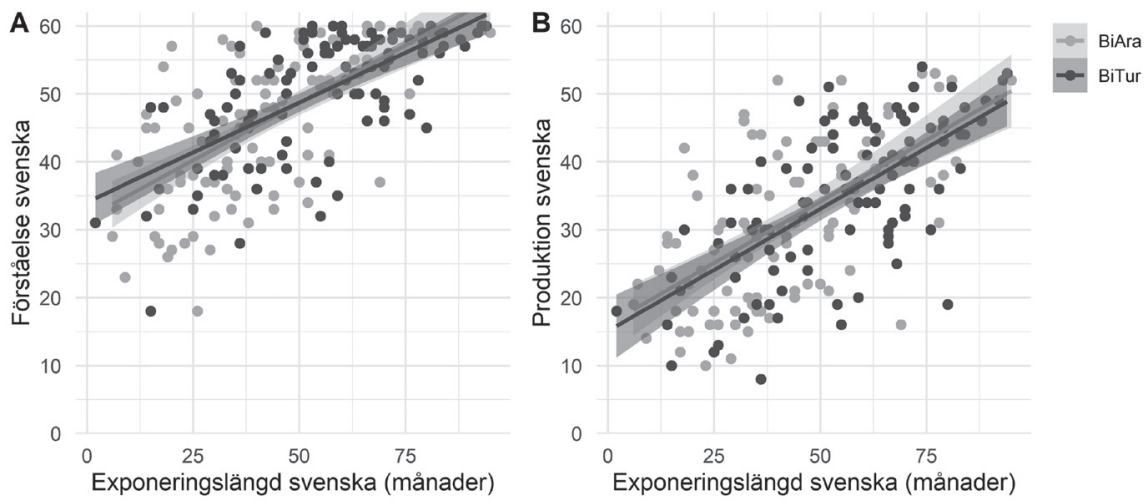

Figur 3. Exponeringslängd och ordförståelse, svenska ( $\max =60)(A)$, samt ordproduktion, svenska $(\max =60)(B)$, individuella barns resultat. En punkt kan ange resultatet för fler än ett barn. Det skuggade området kring regressionslinjen ger ett konfidensintervall på \pm 1 standardfel. BiAra $=$ arabiska/svenska, BiTur $=$ turkiska/svenska.

\subsection{Exponering för minoritetsspråket:}

\section{Föräldrarnas språk till barnet}

Merparten av barnen, 79 arabisktalande och 68 turkisktalande, hörde mestadels arabiska/turkiska från båda föräldrarna. Dessa barn jämfördes med resterande barn, där en förälder eller båda föräldrarna i betydande omfattning talade med barnet på ett annat språk (exv. svenska). Barn vars föräldrar talade enbart eller mestadels minoritetsspråket med dem hade signifikant bättre resultat på förståelse och produktion i minoritetsspråket jämfört med barn som hade andra inputförhållanden (Welchs t-test), vilket visas i tabell 6. Skillnaden visualiseras med låddiagram i figur $4 \mathrm{~A}-\mathrm{B}$. 
Tabell 6. CLT-resultat i relation till föräldrarnas språk till barnet.

\begin{tabular}{lcccl}
\hline & $\mathrm{M}_{\text {mest min-spr }}$ & $\mathrm{M}_{\text {annat }}$ & $\mathrm{t}$-test & $\begin{array}{l}\text { Effektstyrka } \\
\text { Cohens d }\end{array}$ \\
\hline $\begin{array}{l}\text { Ordförståelse } \\
\text { arabiska }\end{array}$ & 49,0 & 41,6 & $\mathrm{t}(23,65)=3,42, \mathrm{p}<0,01$ & $\mathrm{~d}=0,95$ \\
$\begin{array}{l}\text { Ordproduktion } \\
\text { arabiska }\end{array}$ & 34,9 & 23,4 & $\mathrm{t}(30,05)=4,12, \mathrm{p}<0,001$ & $\mathrm{~d}=1,02$ \\
$\begin{array}{l}\text { Ordförståelse } \\
\text { turkiska }\end{array}$ & 55,4 & 52,0 & $\mathrm{t}(49,16)=2,19, \mathrm{p}<0,05$ & $\mathrm{~d}=0,49$ \\
$\begin{array}{l}\text { Ordproduktion } \\
\text { turkiska }\end{array}$ & 42,1 & 33,2 & $\mathrm{t}(48,69)=3,43, \mathrm{p}=0,001$ & $\mathrm{~d}=0,77$ \\
\hline
\end{tabular}

Not. mest min-spr = båda föräldrar talar mestadels minoritetsspråket (arabiska eller turkiska) till barnet.
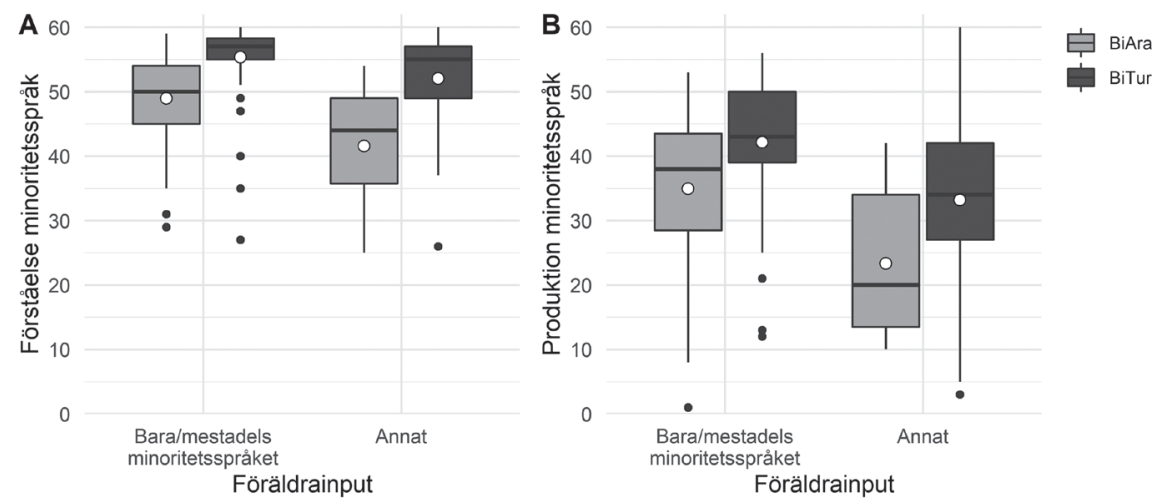

Figur 4. Föräldrainput och ordförståelse på minoritetsspråket (A) samt ordproduktion på minoritetsspråket $(\mathrm{B})$. BiAra $=$ arabiska/svenska, BiTur $=$ turkiska/svenska. Den vita pricken visar medelvärdet.

\subsection{Modersmålsundervisning (MMU)}

Merparten av barnen, 65 arabisktalande och 57 turkisktalande, deltog i modersmålsundervisning (MMU). I den arabisktalande gruppen hade barnen med MMU signifikant högre poäng på ordförrådstesten (både förståelse och produktion) än de barn som inte deltog, vilket framgår i tabell 7. I den turkisktalande 
gruppen fanns ingen sådan signifikant skillnad (även om resultaten verkar gå i samma riktning som för den arabisktalande gruppen, se diskussion).

Tabell 7. CLT-resultat för barn som deltar/inte deltar i modersmålsundervisning (MMU).

\begin{tabular}{lcccc}
\hline & $\mathrm{M}_{\text {ejMmu }}$ & $\mathrm{M}_{\mathrm{MMU}}$ & $\mathrm{t}$-test & $\begin{array}{l}\text { Effektstyrka } \\
\text { Cohens d }\end{array}$ \\
\hline $\begin{array}{l}\text { Ordförståelse } \\
\text { arabiska }\end{array}$ & 43,7 & 49,6 & $\mathrm{t}(45,99)=-3,59, \mathrm{p}<0,001$ & $\mathrm{~d}=-0,82$ \\
$\begin{array}{l}\text { Ordproduktion } \\
\text { arabiska }\end{array}$ & 27,3 & 35,9 & $\mathrm{t}(49,08)=-3,29, \mathrm{p}<0,01$ & $\mathrm{~d}=-0,75$ \\
$\begin{array}{l}\text { Ordförståelse } \\
\text { turkiska }\end{array}$ & 53,9 & 54,4 & $\mathrm{t}(89,53)=-0,41, \mathrm{p}=0,68$ & \\
$\begin{array}{l}\text { Ordproduktion } \\
\text { turkiska }\end{array}$ & 37,4 & 40,8 & $\mathrm{t}(93,91)=-1,47, \mathrm{p}=0,14$ & \\
\hline
\end{tabular}

\subsection{Socio-ekonomisk status}

Barnen delades in i två grupper, låg SES respektive hög SES, enligt föräldrarnas utbildningsnivå (se avsnitt 3.2.3). När SES-data saknades för båda föräldrarna ingick barnet inte i analysen (11/202 barn). I den arabisktalande gruppen var andelen barn med (självrapporterade) högskoleutbildade föräldrar högre än i den turkisktalande gruppen. För inget av ordförrådsmåtten fanns någon inverkan av SES på barnens prestation i någon grupp, varken på majoritetsspråket svenska eller på minoritetsspråket, och varken för ordförståelse eller ordproduktion. ${ }^{10}$

\section{Diskussion}

Denna studie har undersökt ordkunskaperna hos 202 flerspråkiga arabisktalande och turkisktalande barn i åldrarna 4 till 7 år. Studien är unik i en

${ }^{10}$ Ordförståelse arabiska: $\mathrm{M}_{\text {lågSES }}=47,6, \mathrm{M}_{\text {högSES }}=48,0(\mathrm{t}(47,06)=-0,21, \mathrm{p}=0,83)$. Ordproduktion arabiska: $\mathrm{M}_{\text {lågSES }}=36,1, \mathrm{M}_{\text {högSES }}=31,5(\mathrm{t}(62,64)=1,82, \mathrm{p}=0,07)$. Ordförståelse turkiska: $\mathrm{M}_{\text {lågSES }}=53,8, \mathrm{M}_{\text {högSES }}=54,6(\mathrm{t}(94,93)=-0,63, \mathrm{p}=0,53)$. Ordproduktion turkiska: $\mathrm{M}_{\text {lăgSES }}=39,9$, $\mathrm{M}_{\text {högSES }}=37,8(\mathrm{t}(88,11)=0,86, \mathrm{p}=0,39)$. 
svensk kontext eftersom både ordförståelse och ordproduktion har undersökts för en jämförelsevis stor grupp barn, på både majoritetsspråket svenska och på minoritetsspråket. Detta har gjorts med ordförrådstest (CLT) som inte är översättningar utan utvecklade för de olika språken och som är jämförbara mellan språken.

Trots att flerspråkiga barns ordförråd är fördelat över språken och trots att den individuella variationen är stor, visade resultaten på en tydlig åldersutveckling för såväl ordförståelse som ordproduktion. ${ }^{11}$ På så vis stämmer resultaten överens med utvecklingsmönstret för CLT som rapporterats tidigare för enspråkiga barn på 17 språk (Haman m.fl. 2017a, se även Lindgren 2017 för svenska). ${ }^{12}$

Resultaten för ordförståelse var bättre än för ordproduktion i alla åldrar och för alla språk. När det gällde ordförståelse (framför allt på minoritetsspråket) var de yngre barnens resultat mer spridda, medan de äldre barnens var mer samlade. För ordproduktion sågs ingen liknande minskning i variation. De turkisktalande barnen som grupp presterade bättre på ordförståelse på minoritetsspråket än de arabisktalande barnen. Gällande svensk ordförståelse och ordproduktion presterade de båda grupperna relativt lika.

I båda grupperna sågs en tydlig åldersutveckling i ordförrådet $\mathrm{i}$ båda språken, dock var den starkare för majoritetsspråket svenska än för hemspråket turkiska respektive arabiska. Detta är i linje med internationella studier som har funnit en liknande trend hos flerspråkiga förskolebarn och barn i yngre skolåldern i andra länder, exv. för spanska/engelska i USA (Cobo-Lewis m.fl. 2002a, 2002b, Hoff m.fl. 2014), för ryska/tyska i Tyskland (Gagarina m.fl. 2017, Montanari m.fl. 2018), för walesiska/engelska i Wales (Gathercole m.fl. 2013), eller för ryska/hebreiska i Israel (Gagarina m.fl. 2014). I ett svenskt sammanhang påminner den starkare ordförrådsutvecklingen i majoritetsspråket om liknande mönster i en grupp tysk-svensktalande förskolebarn (Lindgren \& Bohnacker 2020) och Ganuza och Hedmans studie (2019) av bl.a. ordförrådet hos äldre somaliska-svensktalande skolelever.

11 Ålder kan anses vara en proxy för ackumulerad språklig input, men även för utveckling av allmänna kognitiva färdigheter och omvärldskunskap.

${ }_{12}$ De arabisktalande och turkisktalande barnens svenska resultat ligger i genomsnitt lägre än hos enspråkiga svenska barn (se Bohnacker m.fl. 2020, för en statistisk jämförelse med åldersmatchade enspråkiga barn). Merparten av de flerspråkiga barnen presterar inte nära maximum på CLT, särskilt inte på ordproduktionsdelarna. Utifrån dessa resultat kan vi alltså inte dra slutsatsen att en genomsnittlig flerspråkig 5-, 6- eller 7-åring kan förväntas »klara av» CLTproduktionsdelarna. 
Trots en tydlig utveckling med stigande ålder på gruppnivå uppvisade barnen stor individuell variation i sin receptiva och expressiva ordkunskap, och denna variation verkade heller inte avta med stigande ålder (bortsett från ordförståelse i minoritetsspråket, som nämnts ovan). Detta innebär att ordförrådsutvecklingen hos de flerspråkiga barnen måste vara starkt påverkad av andra faktorer än kronologisk ålder. Även om vi i föreliggande studie inte använt oss av multivariata modeller (jfr Prevoo m.fl. 2014, Bohnacker m.fl. 2016), ${ }^{13}$ så undersökte vi ett flertal bakgrunds- och miljöfaktorer som delvis kan förklara resultaten.

Exponeringslängden för svenska visade sig ha ett starkt, positivt samband med ordförståelse och ordproduktion på svenska, och detta gällde i lika hög utsträckning för den arabisktalande och den turkisktalande gruppen. Skillnaden mellan grupperna består snarare i att en större andel av de arabisktalande barnen exponerats för svenska en kortare tid. Effekten av exponeringslängden är dock densamma för båda grupperna. Eftersom exponeringslängden för majoritetsspråket brukar vara relaterad till den kumulativa exponeringsmängden, är resultatet inte förvånande och ligger i linje med internationell forskning (Gagarina m.fl. 2017). Vår studie dokumenterar denna relation mellan exponeringslängd och ordförråd för första gången i en svensk kontext för flerspråkiga barn i förskoleåldern.

Angående exponering för minoritetsspråket undersökte vi föräldrarnas rapporterade språk till barnet. Här sågs en tydlig effekt: Barn vars föräldrar talade enbart eller mestadels minoritetsspråket med dem hade bättre resultat i minoritetsspråket jämfört med barn med andra inputförhållanden. Detta gällde för både den arabisktalande och den turkisktalande gruppen. Det finns givetvis andra inputgivare, så som syskon, släktingar, vänner och lekkamrater, personal inom (för)skolan, samt medier. I föreliggande studie har vi dock för enkelhetens skull valt att koncentrera oss på föräldrarnas språkanvändning eftersom den tenderar att samvariera med andra inputgivares och internationellt anses vara en av de viktigaste eller till och med den viktigaste exponeringsfaktorn för minoritetsspråket för den aktuella åldersgruppen. Med hjälp av enkätdatan planerar vi framöver att även undersöka effekter av andra inputkällor inom och utanför familjen. Exempelvis vore det intressant att belysa huruvida syskonens språkanvändning med barnet relaterar till ordförrådsresultat, eftersom en amerikansk studie funnit att äldre syskons användning av majoritetsspråket

\footnotetext{
${ }^{13}$ För multivariata analyser hänvisas till författarnas kommande avhandlingar och framtida publikationer.
} 
i hemmet styr yngre syskon över till majoritetsspråket, vilket kan leda till att ordförrådsutvecklingen i minoritetsspråket stagnerar (Bridges \& Hoff 2014). För barn som får mindre input på minoritetsspråket från föräldrarna vore det också intressant att veta om det finns kompenserande inputkällor, så som den uppvägande »kompiseffekten» i Bohnacker m.fl. (2016), där barn som fick mindre input på minoritetsspråket från föräldrarna men som hade tysktalande respektive turkisktalande vänner hade ett större expressivt ordförråd på detta språk än de utan sådana vänner. Även kvalitativa skillnader i input, exv. olika språkliga aktiviteter så som gemensam bokläsning och berättande på minoritetsspråket, skulle kunna undersökas, då rådata finns i form av enkätsvaren.

Sverige är ett av få länder som erbjuder modersmålsundervisning (MMU), och eftersom gynnsamma effekter av deltagande i MMU på ordförrådsutvecklingen har dokumenterats (Ganuza \& Hedman 2019), undersökte även vi om det fanns en effekt av MMU. Det ska dock sägas att vår studie skiljer sig metodologiskt, inte minst angående deltagarnas ålder (Ganuza \& Hedman 2019: 6-12 år; vår studie: 4-7 år). Jämfört med exponeringen för minoritetsspråket i hemmet är mängden MMU inte särskilt omfattande (ofta 40-60 min/ vecka). I vår studie är barnen så pass unga att de inte kunnat delta i MMU särskilt länge. Det är alltså möjligt att de därmed inte kunnat ackumulera den positiva effekten av MMU på ordinlärningen (eller den positiva effekten av läsning och skrivning på modersmålet, eftersom de allra flesta barnen inte är läskunniga ännu). För den turkisktalande gruppen fanns ingen skillnad i testresultaten mellan de barn som deltog i turkisk MMU och de som inte deltog. I den arabisktalande gruppen fanns dock en skillnad: Barn som deltog i arabisk MMU hade signifikant bättre resultat på arabisk ordförståelse och ordproduktion än de som inte deltog. Varför syns en effekt i den arabisktalande gruppen men inte i den turkisktalande gruppen? Här kan vi bara spekulera. Det finns en viss snedfördelning, där andelen sex- och sjuåringar som deltar i MMU är något högre $\mathrm{i}$ den arabisktalande gruppen än i den turkisktalande gruppen, och vi vet att äldre barn når högre testresultat. Detta kan dock inte vara hela förklaringen. En möjlighet är att den enkla tudelningen (MMU eller ej) döljer skillnader i mängd och/eller kvalitet. I föräldraenkäten efterfrågades om barnet deltog i MMU, men även om detta skedde i kommunal eller privat regi, och tillsammans med andra barn eller ej, samt antalet timmar MMU per vecka det rörde sig om. En närmare granskning visar att de barn som deltog i MMU på turkiska fick avsevärt färre undervisningstimmar än de som deltog i MMU på arabiska, i genomsnitt endast hälften så mycket (turkiska: $\mathrm{M}=0,9$ tim/vecka, arabiska: $\mathrm{M}=1,9$ tim/vecka). Vi förmodar att det även finns skillnader i vilka 
barn som deltar i MMU i turkiska och MMU i arabiska. När vi intervjuade modersmålspedagoger för de aktuella språken påpekade de att $\mathrm{i}$ en och samma turkiska-klass samsades oftast deltagare i olika åldrar och med helt olika förkunskaper i turkiska. Enligt dessa modersmålslärare i turkiska kunde en betydande andel barn som började delta i MMU knappt säga något alls på turkiska och ibland inte heller förstå, utan de hade skickats dit av föräldrarna »för att lära sig turkiska». Modersmålslärarna i arabiska uttryckte mycket sällan sådana synpunkter, de menade snarare att barnen oftast kunde tala arabiska bra eller ganska bra hemifrån. I stället nämnde de som den största utmaningen att barnen i samma MMU-klass, och ibland även läraren, ofta talar olika arabiska dialekter, vilket kan leda till missförstånd och andra kommunikationsproblem. Även om modersmålspedagogernas erfarenheter är impressionistiska, så tyder de ändå på att det kan finnas skillnader i elevsammansättningen i en genomsnittlig MMU-klass i turkiska gentemot i arabiska. I så fall skulle de bättre testresultaten hos barn som deltog i MMU i arabiska inte spegla en gynnsam MMU-effekt, utan snarare en skillnad i urvalet.

Angående socio-ekonomisk status (SES) fann vi inte någon mätbar inverkan på barnens testprestation i någon av grupperna, varken på majoritetsspråket svenska eller på minoritetsspråket, och varken för ordförståelse eller ordproduktion. Detta resultat går emot flertalet internationella studier som, åtminstone för majoritetsspråket, funnit tydliga effekter av SES, där barn med högre SES i genomsnitt har större ordförråd och presterar bättre på ordkunskapstest än barn med lägre SES (Leseman 2000, Cobo-Lewis m.fl. 2002a, 2002b, Pearson 2007, Buac m.fl. 2014, Calvo \& Bialystok 2014, Prevoo m.fl. 2014, Meir \& Armon-Lotem 2017). Varför ser vi ingen sådan SES-effekt i våra data? Här kan det finnas flera förklaringar. En ligger i hur SES operationaliseras, där vi valt att använda medelvärdet på föräldrarnas utbildningsnivåer som mått på SES och dragit gränsen för hög/låg SES vid ISCED 3, d.v.s. eftergymnasial utbildning eller ej. Detta är ingen ovanlig operationalisering, men en del andra studier har använt sig av endast mammans utbildningsnivå (och inte båda föräldrars), eller av föräldrarnas yrke, familjens inkomst, bostadsområde, om barnet är berättigat till gratis skollunch för behövande, eller en sammanvägning av några av dessa aspekter. Det är också tänkbart att SES påverkar olika ordförrådsmått på olika sätt, där ovanstående studier har använt sig av andra ordförrådstest än vi. Ytterligare en förklaring till varför vi, i motsats till studier i andra länder, inte funnit någon effekt av SES kan ha att göra med den svenska kontexten, utbildningsnivån och välfärdsstaten. Utbildningsnivån i våra deltagargrupper (och i Sverige som helhet) är relativt hög, med få för- 
äldrar som inte är läs- och skrivkunniga. Extrem fattigdom är också ovanlig i Sverige. I internationell forskning anförs ofta att SES ger så tydligt utslag på ordförrådet eftersom barn från familjer med hög SES får bättre tillgång till språkliga aktiviteter som stimulerar utveckling och ordinlärning än barn från familjer med låg SES (Hart \& Risley 1995, Pearson 2007). I Sverige är tillgången till vård, förskola och skola inte så tätt kopplad till familjens inkomst och utbildningsnivå jämfört med i många andra länder, och det erbjuds förskoleplats till alla barn från mycket tidig ålder. Nästan alla barn går också i förskola, och de flesta på heltid (så är även fallet för de flesta deltagarna i vår studie). Detta kan innebära att den direkta effekten av skillnader i SES i viss mån jämnas ut i förskole- och tidig skolålder i Sverige. Språkutvecklingen i förskole- och tidiga skolåldern, och i vårt fall ordförrådsutvecklingen, skulle då inte påverkas så mycket av familjens SES i sig, utan mer av mängden och kvaliteten på input i (för)skolan, samt av språkanvändning och språkstimulerande aktiviteter i hemmet. ${ }^{14}$

Vi har sett stor individuell variation i ordförrådsutvecklingen, en variation som inte enbart kan förklaras med faktorerna ålder och exponeringslängd. Några bakgrunds- och miljöfaktorer har här undersökts på gruppnivå (föräldrarnas språk till barnet, deltagande i modersmålsundervisning, och föräldrarnas utbildningsnivå). Men i vårt sampel om 202 barn är varje barns ordkunskaper ett resultat av många faktorer, där vissa är lätta att mäta, medan andra är mer svårfångade och inte endast har med miljön att göra utan även med det individuella barnet självt. Avslutningsvis vill vi därför illustrera denna komplexitet med att titta närmare på fyra barn.

Tabell 8 jämför två barn som talar arabiska och svenska, en 4-årig flicka med mycket höga arabiska CLT-poäng (BiAra4-24) och en 7-årig flicka med mycket låga resultat på arabiska, särskilt för ordproduktion (BiAra7-12), och deras respektive bakgrund. Båda barnens föräldrar växte upp i ett arabisktalande land och har arabiska som modersmål. SES är låg i båda fallen, men här slutar likheterna. Vid testtillfället har BiAra4-24s familj vistats i Sverige i 3 år, föräldrarna och syskonen talar arabiska med barnet och hon exponeras för svenska i förskolan (från 3 års ålder). Det bör noteras att familjen nästan dagligen genomför aktiviteter med barnet i hemmet som stimulerar språk och

${ }^{14}$ Det är möjligt att effekten av SES framträder tydligare ju äldre barnen blir, d.v.s. att ovannämnda faktorer kanske har en utjämnande effekt i tidiga åldrar men inte tillräckligt för att motverka senare ojämlikheter. I den årliga betygsstatistiken för årskurs 9 (Skolverket 2020) syns t.ex. tydligt att barn med lågutbildade föräldrar presterar genomsnittligt sämre än barn med högutbildade föräldrar (där båda har eftergymnasial utbildning). 
litteracitet, och att barnets modersmålsundervisning (i privat regi) är ovanligt omfattande. Det finns fog att anta att dessa aktiviteter bidrar positivt till ordförrådsutvecklingen i arabiska hos detta högpresterande barn. BiAra7-12 är däremot född i Sverige, hennes föräldrar har bott i Sverige i många år, hon började gå i svensk förskola vid mycket tidig ålder och den dagliga exponeringen är mestadels svenska. Föräldrarna och syskonen talar både arabiska och svenska med barnet. Svenskan har blivit det dominerande språket för BiAra712 (hon har mycket höga svenska CLT-poäng) och det är möjligt att hennes tvåspråkighet går mot att bli enbart receptiv, eftersom den arabiska ordproduktionen är mycket låg.

Tabell 8. Mycket höga CLT-poäng i arabiska vid 4 år. Mycket låga CLT-poäng i arabiska vid 7 år.

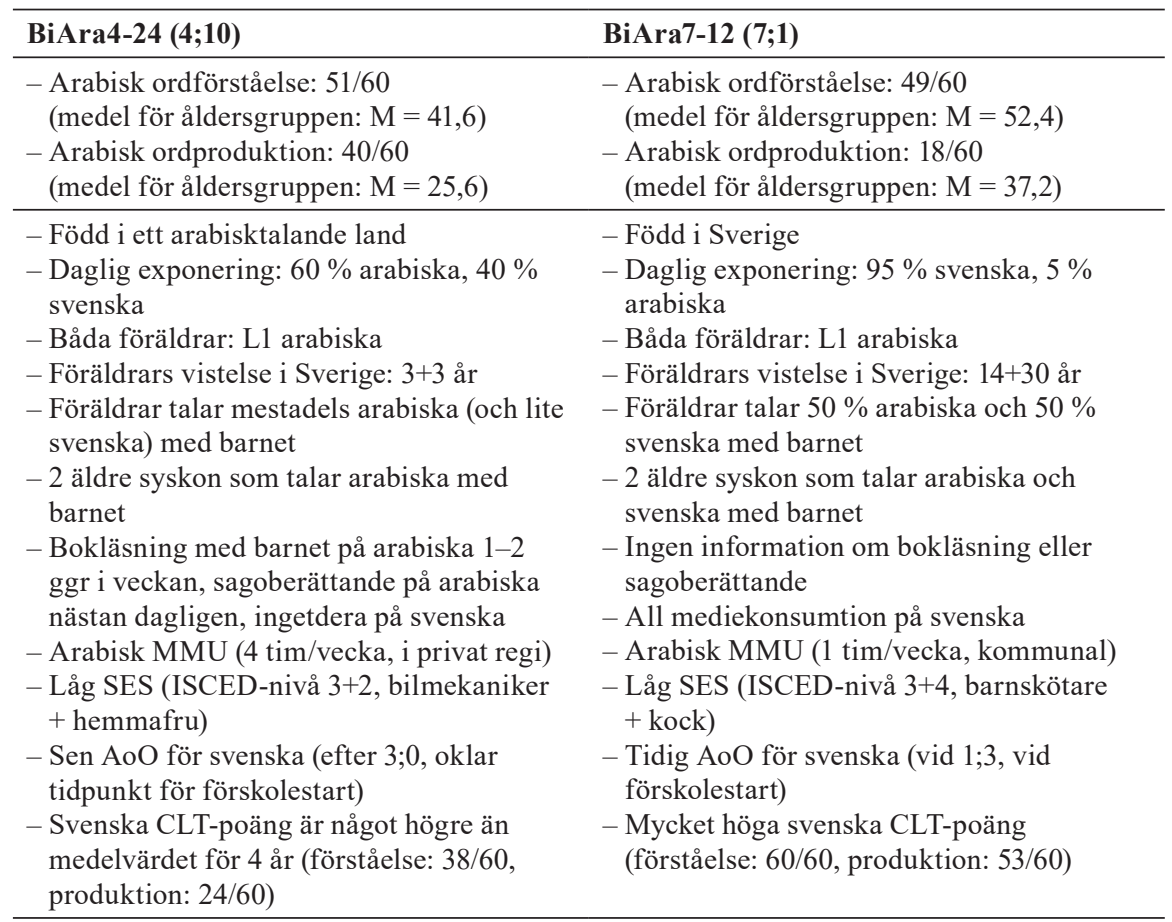

Not. $\mathrm{L} 1$ = modersmål. $\mathrm{AoO}$ = ålder vid första regelbundna exponering för svenska.

Tabell 9 jämför två arabisktalande sjuåringar (BiAra7-15, BiAra7-17) med till synes liknande bakgrund men med helt olika ordförrådsresultat. Båda barn är 
födda i ett arabisktalande land och kom till Sverige endast 3 år innan testtillfället. Samtliga föräldrar har arabiska som modersmål och talar nästan enbart arabiska med barnet. Genomsnittlig SES är låg. Båda barnen deltar i modersmålsundervisning. För båda började exponeringen för svenska $(\mathrm{AoO})$ sent, vid 5 års ålder, via förskolan. Trots detta uppvisar BiAra7-15 mycket höga CLTpoäng på både svenska och arabiska; ordförståelsen är nära testmaximum på båda språken, och även ordproduktionen är mycket hög, trots sen startålder för svenska. I motsats till detta är BiAra7-17s CLT-poäng låga på både svenska och arabiska.

När vi studerar barnens bakgrund mer ingående uppdagas ändå skillnader i miljö och individuella drag som kan ha påverkat ordförrådsutvecklingen. Föräldrarna till högpresterande BiAra7-15 rapporterar att de nästan varje dag läser böcker för barnet och har sagostunder med henne. BiAra7-17s föräldrar rapporterar få liknande aktiviteter. BiAra7-15 vistades i förskolan dubbelt så mycket som BiAra7-17 (30 vs 15 tim/vecka). BiAra7-17 bytte dessutom (för)skola flera gånger eftersom familjen flyttade, och var hemma en längre tid i väntan på en skolplats, vilket skulle kunna förklara varför BiAra7-17s svenska ordförråd inte är särskilt välutvecklat. BiAra7-15 karakteriseras av sina föräldrar som early talker (d.v.s. ett barn som börjar tala ovanligt tidigt) och som ett barn som utvecklar sitt språk snabbare än andra jämnåriga barn. I motsats till detta beskriver BiAra7-17s föräldrar att deras barn är fascinerat av engelska och spenderar mycket av sin tid med att titta på engelska filmklipp på nätet och med att spela videospel på engelska. Som en följd av detta tillbringar BiAra7-17 mindre tid med att umgås med andra på arabiska och svenska. Tillsammans med ovannämnda förskolebyten kan detta ha bidragit till barnets låga prestationer på arabiska och svenska ordförrådstest. 
Tabell 9. Två flerspråkiga sjuåringar med liknande bakgrund men mycket olika CLT-poäng.

\begin{tabular}{|c|c|}
\hline BiAra7-15 (7;10) & BiAra7-17 (7;11) \\
\hline $\begin{array}{l}\text { - Svenska ordförståelse: } 57 / 60 \\
\text { (medel för åldersgruppen: } M=53,3 \text { ) } \\
\text { - Svenska ordproduktion: } 44 / 60 \\
\text { (medel för åldersgruppen: } M=29,5 \text { ) }\end{array}$ & $\begin{array}{l}\text { - Svensk ordförståelse: } 44 / 60 \\
\text { (medel för åldersgruppen: } M=53,3 \text { ) } \\
\text { - Svensk ordproduktion: } 20 / 60 \\
\text { (medel för åldersgruppen: } M=29,5 \text { ) }\end{array}$ \\
\hline $\begin{array}{l}\text { - Född i ett arabisktalande land } \\
\text { - Daglig exponering: } 40 \% \text { arabiska, } 60 \% \\
\text { svenska } \\
\text { - Båda föräldrar: L1 arabiska } \\
\text { - Föräldrars vistelse i Sverige: } 3+3 \text { år } \\
\text { - Föräldrar talar endast arabiska med barnet }\end{array}$ & $\begin{array}{l}\text { - Född i ett arabisktalande land } \\
\text { - Daglig exponering: } 40 \% \text { arabiska, } 40 \% \\
\text { svenska, } 20 \% \text { engelska (videospel) } \\
\text { - Båda föräldrar: L1 arabiska } \\
\text { - Föräldrars vistelse i Sverige: } 3+3 \text { år } \\
\text { - Föräldrar talar nästan bara arabiska med } \\
\text { barnet en förälder talar lite engelska }\end{array}$ \\
\hline $\begin{array}{l}\text { - Äldre syskon talar arabiska med barnet } \\
\text { - Bokläsning och sagoberättande med barnet } \\
\text { på svenska nästan dagligen, bokläsning } \\
\text { och sagoberättande på arabiska } 1-2 \text { ggr i } \\
\text { veckan }\end{array}$ & $\begin{array}{l}\text { - Äldre syskon talar arabiska med barnet } \\
\text { - Bokläsning med barnet på svenska 1-2 } \\
\text { ggr/vecka, ingen på arabiska, sagoberät- } \\
\text { tande på arabiska } 1-2 \text { ggr/vecka, ingen på } \\
\text { svenska }\end{array}$ \\
\hline - Arabisk MMU (1,5 tim/vecka, kommunal) & - Arabisk MMU (1,5 tim/vecka, kommunal) \\
\hline $\begin{array}{l}\text { - Låg SES (ISCED-nivå 2+3, guldsmed + } \\
\text { försäljare) }\end{array}$ & $\begin{array}{l}\text { - Blandad SES (ISCED-nivå 6+2, ingenjör } \\
\text { + arbetslös) }\end{array}$ \\
\hline $\begin{array}{l}\text { - Sen AoO för svenska (efter 5;0, förskole- } \\
\text { start vid } 4 \text { år, tid i förskolan } 30 \text { tim/vecka, } \\
\text { med } 3 \text { månaders uppehåll) }\end{array}$ & $\begin{array}{l}\text { - Sen AoO för svenska (efter 5;0, förskole- } \\
\text { start vid 4;9, tid i förskolan } 15 \text { tim/vecka) }\end{array}$ \\
\hline $\begin{array}{l}\text { - Mycket höga arabiska CLT-poäng (förstå- } \\
\text { else: 58/60, produktion: 44/60) }\end{array}$ & $\begin{array}{l}\text { - Arabiska CLT-poäng är låga för } 7 \text { år (för- } \\
\text { ståelse: } 47 / 60 \text {, produktion: } 27 / 60 \text { ) }\end{array}$ \\
\hline
\end{tabular}

\section{Avslutning}

Föreliggande studie har undersökt ordförrådsutvecklingen hos 202 flerspråkiga barn på majoritetsspråket svenska och minoritetsspråket arabiska respektive turkiska i relation till ålder och ett antal miljöfaktorer. Vi fann tydliga effekter av kronologisk ålder, exponeringslängd för svenska och föräldrarnas språkanvändning av minoritetsspråket. Vi fann även en svag och mer svårtydd effekt av modersmålsundervisning men inga effekter av föräldrarnas utbildningsnivå (SES) på ordförrådet i den aktuella åldersgruppen. Mycket återstår att utforska. Till exempel skulle interaktionen mellan dessa faktorer också behöva undersökas, liksom effekten av ytterligare faktorer, så som andra inputkällor. 
Vidare bör tilläggas att även om vi här kunnat dokumentera tydliga åldersoch exponeringseffekter på gruppnivå, behöver dessa inte vara utslagsgivande för hur ett specifikt barn utvecklas. Långvarig exponering leder inte alla gånger till att ett flerspråkigt barn utvecklar ett rikt ordförråd. Användningen av minoritetsspråket $\mathrm{i}$ hemmet garanterar heller inte att barnet förvärvar tillfredställande ordkunskaper i detta språk. Som fallstudierna ovan illustrerar kan barn förvärva goda ordkunskaper i ett nytt språk även under en relativt kort tidsperiod - men bara om miljön och den språkliga inputen är gynnsam.

\section{Litteratur}

Ahlström, Lovisa \& Ljungman, Helena, 2011: Åldersreferenser för Peabody Picture Vocabulary Test IV på svenska för flerspråkiga barn i skolår 4. Opublicerad magisteruppsats. Stockholm: Karolinska institutet.

Altman, Carmit, Goldstein, Tamara \& Armon-Lotem, Sharon, 2017: Quantitative and qualitative differences in the lexical knowledge of monolingual and bilingual children on the LITMUS-CLT task. I: Clinical Linguistics \& Phonetics 31(11-12). S. 931-954.

Bialystok, Ellen, Luk, Gigi, Peets, Kathleen F. \& Yang, Sujin, 2010: Receptive vocabulary differences in monolingual and bilingual children. I: Bilingualism: Language and Cognition 13(4). S. 525-531.

Boeschoten, Hendrik \& Verhoeven, Ludo, 1986: Turkish language development of Turkish children in the Netherlands. I: Proceedings of the Turkish Linguistics Conference, August 9-10, 1984, red. av Ayhan Aksu Koç \& Taylan Eser Erguvanli. Istanbul: Boğaziçi University. S. 269-280.

Bohnacker, Ute, 2013-2019: Language impairment or typical language development? Developing methods for linguistic assessment of bilingual children in Sweden. Projekt 421-2013-1309 är finansierat av Vetenskapsrådet och förkortas »BiLI-TAS» (Bilingualism, Language Impairment, Turkish, Arabic, Swedish).

Bohnacker, Ute (i samarbete med Sibylle Dillström, Josefin Lindgren \& Buket Öztekin), 2018: Guidelines for Scoring CLT. Opublicerat material. Guidelines developed for the BiLI-TAS project Version March 2018. Uppsala: Uppsala universitet.

Bohnacker, Ute, Haddad, Rima, Lindgren, Josefin, Öberg, Linnéa \& Öztekin, Buket, 2020. Ordförrådsutveckling på svenska: En jämförelse mellan enspråkiga och flerspråkiga förskolebarn. I: Svenskans beskrivning 37: Förhandlingar vid trettiosjunde sammankomsten Åbo 8-10 maj 2019, red. av Saara Haapamäki, Ludvig Forsman \& Linda Huldén. Åbo: Åbo akademi. S. 70-82.

Bohnacker, Ute, Haddad, Rima \& Öberg, Linnéa, under granskning: Arabic-Swedish bilingual children living in Sweden: Vocabulary skills in relation to age, SES and language exposure. I: Journal of Home Language Research. 
Bohnacker, Ute, Lindgren, Josefin \& Öztekin, Buket, 2016: Turkish- and Germanspeaking bilingual 4-to-6-year-olds living in Sweden: Effects of age, SES and home language input on vocabulary production. I: Journal of Home Language Research 1. S. 17-40.

Bridges, Kelly \& Hoff, Erika, 2014: Older sibling influences on the language environment and language development of toddlers in bilingual homes. I: Applied Psycholinguistics 35(2). S. 225-241.

Buac, Milijana, Gross, Megan, \& Kaushanskaya, Margarita, 2014: The role of primary caregiver vocabulary knowledge in the development of bilingual children's vocabulary skills. I: Journal of Speech, Language and Hearing Research 57(5). S. 1804-1816.

Calvo, Alejandra \& Bialystok, Ellen, 2014: Independent effects of bilingualism and socioeconomic status on language ability and executive functioning. I: Cognition 130(3). S. 278-288.

Cobo-Lewis, Alan B., Pearson, Barbara Zurer, Eilers, Rebecca E. \& Umbel, Vivian C., 2002a: Effects of bilingualism and bilingual education on oral and written English skills: A multi-factor study of standardized test outcomes. I: Language and literacy in bilingual children, red. av D. Kimbrough Oller, \& Rebecca E. Eilers. Clevedon: Multilingual Matters. S. 64-97.

Cobo-Lewis, Alan B., Pearson, Barbara Zurer, Eilers, Rebecca E. \& Umbel, Vivian C., 2002b: Effects of bilingualism and bilingual education on oral and written Spanish skills: A multi-factor study of standardized test outcomes. I: Language and literacy in bilingual children, red. av D. Kimbrough Oller, \& Rebecca E. Eilers. Clevedon: Multilingual Matters. S. 98-117.

Dunn, Lloyd M. \& Dunn, Douglas M., 2007: Peabody Picture Vocabulary Test (PPVTIV) (fourth edition). Bloomington, MN: Pearson Assessment.

Fenson, Larry, Dale, Philip, Reznick, J. Steven, Bates, Elizabeth, Thal, Donna J. \& Pethick, Steve J., 1994: Variability in early communicative development. I: Monographs of the Society for Research in Child Development 59 (Serial No. 242).

Frylmark, Astrid, 2006: Bedömning av språk B.A.S. 51/2-71/2 år. Märsta: OrdAF Förlag.

Gagarina, Natalia, Armon-Lotem, Sharon, Altman, Carmit, Burstein-Feldman, Zhanna, Klassert, Annegret, Topaj, Nathalie, Golcher, Felix \& Walters, Joel, 2014: Age, input quantity and their effect on linguistic performance in the home and societal language among Russian-German and Russian-Hebrew preschool children. I: The challenges of diaspora migration: Interdisciplinary perspectives on Israel and Germany, red. av Rainer K. Silbereisen, Peter F. Titzmann \& Yossi Shovit. Farnham, Surrey: Ashgate. S. 63-82.

Gagarina, Natalia, Posse, Dorothea, Düsterhöft, Stefanie, Golcher, Felix \& Topaj, Nathalie, 2017: Bilingual lexicon development in German in preschool children with the home languages Russian and Turkish. I: Dynamics of linguistic diversity, red. av Hagen Peukert \& Ingrid Gogolin. Amsterdam: John Benjamins. S. 125-142. 
Ganuza, Natalia \& Hedman, Christina, 2019: The impact of mother tongue instruction on the development of biliteracy: Evidence from Somali-Swedish bilinguals. I: Applied Linguistics 40(1). S. 108-131.

Gathercole, Virginia C. Mueller, Thomas, Enlli Môn, Roberts, Emily J., Hughes, Catrin O., \& Hughes, Emma K., 2013: Why assessment needs to take exposure into account: Vocabulary and grammatical abilities in bilingual children. I: Issues in the assessment of bilinguals, red. av Virginia C. Mueller Gathercole. Bristol: Multilingual Matters. S. 20-55.

Haddad, Rima, 2017: Crosslinguistic Lexical Tasks: Selected Arabic Dialects. Adapted from the Lebanese version (CLT-ARA). Opublicerat material.

Haman, Ewa, Łuniewska, Magdalena, Hansen, Pernille, Simonsen, Hanne Gram, Chiat, Shula, Bjekić, Jovana, Blažienè, Agne, Chyl, Katarzyna, Dabašinskienè, Ineta, Engel de Abreu, Pascale, Gagarina, Natalia, Gavarró, Anna, Håkansson, Gisela, Harel, Efrat, Holm, Elisabeth, Kapalková, Svetlana, Kunnari, Sari, Levorato, Chiara, Lindgren, Josefin, Mieszkowska, Karolina, Montes Salarich, Laia, Potgieter, Anneke, Ribu, Ingeborg, Ringblom, Natasha, Rinker, Tanja, Roch, Maja, Slančová, Daniela, Southwood, Frenette, Tedeschi, Roberta, Tunçer, Aylin Müge, Ünal-Logacev, Özlem, Vuksanović, Jasmina \& Armon-Lotem, Sharon, 2017a: Noun and verb knowledge in monolingual preschool children across 17 Languages: Data from Cross-Linguistic Lexical Tasks (LITMUS-CLT). I: Clinical Linguistics \& Phonetics 31(11-12). S. 818-843.

Haman, Ewa, Łuniewska, Magdalena \& Pomiechowska, Barbara, 2015: Designing Cross-Linguistic Lexical Tasks (CLTs) for bilingual preschool children. I: Methods for assessing multilingual children: Disentangling bilingualism from language impairment, red. av Sharon Armon-Lotem, Jan de Jong \& Natalia Meir. Bristol: Multilingual Matters. S. 196-239.

Haman, Ewa, Wodniecka, Zofia, Marecka, Marta, Szewczyk, Jakub, Białecka-Pikul, Marta, Otwinowska, Agnieszka, Mieszkowska, Karolina, Łuniewska, Magdalena, Kołak, Joanna, Miękisz, Aneta, Kacprzak, Agnieszka, Banasik, Natalia \& ForyśNogala, Małgorzata, 2017b: How does L1 and L2 exposure impact L1 performance in bilingual children? Evidence from Polish-English migrants to the United Kingdom. I: Frontiers in Psychology 8. Art. 1444.

Hart, Betty \& Risley, Todd R., 1995: Meaningful differences in the everyday experience of young American children. Baltimore: Paul Brookes.

Hoff, Erika, Rumiche, Rosario, Burridge, Andrea, Ribot, Krystal M. \& Welsh, Stephanie N., 2014: Expressive vocabulary development in children from bilingual and monolingual homes: A longitudinal study from two to four years. I: Early Childhood Research Quarterly 29(4). S. 433-444.

Holm, Hedvig \& Rejnö-Habte Selassie, Gunilla, 2017: Svenska normer för flerspråkiga barn på språkförståelsedelen i Reynell Developmental Language Scales III: Betydelsen av socioekonomiska förhållanden. I: Logopeden 2. S. 16-21.

Kroll, Judith \& De Groot, Annette M. B., 2007: Lexical and conceptual memory in the bilingual: Mapping form to meaning in two languages. I: The bilingualism reader, red. av Li Wei. (2:a uppl.) London: Routledge. S. 405-427. 


\section{U. Bohnacker, R. Haddad, J. Lindgren, L. Öberg \& B. Öztekin}

Leseman, Paul, 2000: Bilingual vocabulary development of Turkish preschoolers in the Netherlands. I: Journal of Multilingual and Multicultural Development 21(2). S. 93-112.

Lindgren, Josefin, 2017: Ordförrådsutveckling hos förskolebarn med svenska som modersmål: En studie med Cross-linguistic Lexical Task (CLT). I: Svenskans beskrivning 35: Förhandlingar vid trettiofemte sammankomsten Göteborg 11-13 maj 2016, red. av Emma Sköldberg, Maia Andréasson, Henrietta Adamsson Eryd, Filippa Lindahl, Julia Prentice, Sven Lindström \& Malin Sandberg. (Göteborgsstudier i nordisk språkvetenskap 29.) Göteborg: Göteborgs universitet. S. 161-174.

Lindgren, Josefin \& Bohnacker, Ute, 2020: Vocabulary development in closely-related languages: Age, word type and cognate facilitation effects in bilingual SwedishGerman preschool children. I: Linguistic Approaches to Bilingualism, 10(5). S. 587-622.

Meir, Natalia \& Armon-Lotem, Sharon, 2017: Independent and combined effects of socioeconomic status (SES) and bilingualism on children's vocabulary and verbal short-term memory. I: Frontiers in Psychology 8. Art. 1442.

Montanari, Elke G., Abel, Roman, Graßer, Barbara \& Tschudinovski, Lilia, 2018: Do bilinguals create two different sets of vocabulary for two domains? Vocabulary development and overlap in the first years of schooling. I: Linguistic Approaches to Bilingualism 8(4). S. 502-522.

Pearson, Barbara Zurer, 2007: Social factors in childhood bilingualism in the United States. I: Applied Psycholinguistics 28(3). S. 399-410.

Pearson, Barbara Zurer, Fernández, Sylvia C. \& Oller, D. Kimbrough, 1993: Lexical development in bilingual infants and toddlers: Comparison to monolingual norms. I: Language Learning 43(1). S. 93-120.

Prevoo, Mariëlle J.L., Malda, Maike, Mesman, Judi, Emmen, Rosanneke A.G., Yeniad, Nihal, Van Ijzendoorn, Marinus H. \& Linting, Mariëlle, 2014: Predicting ethnic minority children's vocabulary from socioeconomic status, maternal language and home reading input: Different pathways for host and ethnic language. I: Journal of Child Language 41(5). S. 963-984.

Rhys, Mirain \& Thomas, Enlli Môn, 2013: Bilingual Welsh-English children's acquisition of vocabulary and reading: implications for bilingual children. I: International Journal of Bilingual Education and Bilingualism 16(6). S. 633-656.

Ringblom, Natasha, Håkansson, Gisela \& Lindgren, Josefin, 2014: Cross-Linguistic Lexical Tasks: Swedish version (CLT-SWE). Opublicerat material.

Sheng, Li, Lam, Boji Pak Wing, Cruz, Diana, \& Fulton, Aislynn, 2016: A robust demonstration of the cognate facilitation effect in first-language and second-language naming. I: Journal of Experimental Child Psychology 141. S. 229-238.

Skolverket, 2020: Grundskolan slutbetyg årskurs 9, tabell 7. www.skolverket.se/ skolutveckling/statistik/sok-statistik-om-forskola-skola-och-vuxenutbildning?sok= SokC\&omrade=Betyg\%20\%C3\%A5rskurs\%209\&lasar=2018/19\&run=1 (åtkomst 27 juli 2020).

Thordardottir, Elin, 2011: The relationship between bilingual exposure and vocabulary development. I: International Journal of Bilingualism 15(4). S. 426-445. 
Thordardottir, Elin, 2014: The typical development of simultaneous bilinguals: Vocabulary, morphosyntax and language processing in two age groups of Montreal preschoolers. I: Input and experience in bilingual development, red. av Theres Grüter \& Johanne Paradis. Amsterdam: John Benjamins. S. 141-161.

Ünal-Logacev, Özlem, Tunçer, Aylin, Müge \& Ege, Pınar, 2013: Cross-Linguistic Lexical Tasks: Turkish version (CLT-TR). Opublicerat material.

UNESCO Institute for Statistics, 2012: International Standard Classification of Education: ISCED 2011. Montreal, Quebec: UNESCO Institute for Statistics. http://uis. unesco.org/sites/default/files/documents/international-standard-classification-ofeducation-isced-2011-en.pdf

Unsworth, Sharon, 2013: Current issues in multilingual first language acquisition. I: Annual Review of Applied Linguistics 33. S. 21-50.

Vermeer, Anne, 2001: Breadth and depth of vocabulary in relation to L1/L2 acquisition and frequency of input. I: Applied Psycholinguistics 22(2). S. 217-234.

Öztekin, Buket, 2019: Typical and atypical language development in Turkish-Swedish bilingual children aged 4-7. (Studia Linguistica Upsaliensia 25.) Uppsala: Acta Universitatis Upsaliensis. 